\title{
A Study of Cervical Cytological Changes in Hiv Positive Patients
}

\author{
Dr.Maruthi Devi Karri ${ }^{1}$,Dr.Sudhakar Ghanta ${ }^{2}$,Dr.Padmavathi Devi Chaganti ${ }^{3}$, \\ Dr.Sailabala Garikaparthi ${ }^{4}$ \\ ${ }^{1}$ Assistant Professor In Pathology, Guntur Medical College, Guntur \\ ${ }^{2}$ Associate professor in pathology, Guntur medical college, Guntur \\ ${ }^{3,4}$ Professor In Pathology, Guntur Medical College, Guntur \\ *Corresponding author: Dr.sudhakar Ghanta *
}

\begin{abstract}
:
Background: Gynaecological conditions are extremely common among women infected with Human Immunodeficiency Virus. These include pelvic inflammatory disease, Sexually Transmitted Diseases like syphilis, Herpes, Cytomegalo virus, Vulvovaginal Candidiasis etc.

Objectives: The purpose of the study is to characterize the cervical cytological changes in HIV seropositive women.

Materials \& Methods: This cross sectional study was based on 200 patients with HIVinfection /AIDS, who attended the department of pathology and Gynaecology, Guntur medical college, Guntur.

Results: The study revealed maximum number of inflammatory smears (81.3\%), followed by smears showing squamous intra epithelial lesion (13.82\%).

Conclusion: PAP smear can be recommended as a part of routine medical examination in gynaecological practice as it is a simple, cost effective, low risk procedure.

Keywords: HIV/AIDS, papanicolaou smear, cervix, inflammatory lesions.
\end{abstract}

\section{Introduction}

Over the past decade, the Acquired Immuno Deficiency Syndrome epidemic in India has grown from a handful of Human Immunodeficiency Virus infected persons to a major public health problem with tremendously growing medical, psychological and economic consequences for the country. In India around $22 \%$ of total reported Acquired Immuno Deficiency syndrome cases and around 30\% of newer Human Immunodeficiency Virus infections were among women. Gynaecological conditions are extremely common among women infected with Human Immunodeficiency Virus. These include pelvic inflammatory disease, Sexually Transmitted Diseases like syphilis, Herpes, Cytomegalovirus, Vulvovaginal Candidiasis etc. The HIVseropositive women have higher chances of cervical intra epithelial neoplasia, vaginal intraepithelial neoplasia and vulval intra epithelial neoplasia. Occurence of cervical cancers associated with Human Immunodeficiency Virus infection can be easily prevented if detected early. The cytological findings obtained in this cohort have been presented. The study highlights and ascertains the utility of cervical smear cytology in picking up early premalignant conditions of cervical cancer and associated changes in various infections.

It is thought that the cervical intraepithelial neoplasia is about 15-20 years progresses to invasive cancer. This prolonged natural history along with the exfoliative nature of precancerous lesions, easy accessibility of cervix to inspection, Palpation and application of cytological procedures have lead to extensive screening programmes for early detection and treatment of disease. Thus cytological screening should gain much popularity and should be accessible to all. It is recommended as a part of routine medical examination in gynaecological practice.Papanicolaou smear screening is an adequate tool for detecting cytologic changes in women with Human Immunodeficiency Virus, a group at increase risk for squamous intraepithelial lesion. Cervical cancer is a preventable disease if women receive regular screening and timely followup and treatment after abnormal papanicolaou smear result.

\section{Materials And Methods}

This cross sectional study was based on the patients with HIVinfection /AIDS, with Gynaecological problems, pelvic inflammatory diseases, who were referred to the department of pathology and Gynaecology, Guntur medical college,Guntur from September 2013 to August2015. In the present study 200 cases were included. Pregnant women and post hysterectomised women were excluded from the study.

A thorough history was taken with particular reference to age, socioeconomic status, parity, menstrual history, duration of HIV infection, husband health status, STDs, personal and genital hygiene, opportunistic infections, vaginal discharge, CD4 cell count and ART treatment. Cervix was visualized with Sims speculum and associated conditions like erosion, ectropion, hypertrophy, endocervicitis, suspicious growth on cervix and 
elongation of cervix were noted. After a thorough vaginal examination pap smears were taken. Smears were immediately fixed in isopropyl alchohol and stained according to the Papanicolaou' s technique. Haematoxylin and Eosin staining also used for some cases. The cytological changes observed in the cervical smears were graded according to The Bethesda system of 2001. Smears taken mainly from women of various age groups ranging from $15-49$ years.

\section{Observation And Results}

In this study $200 \mathrm{HIV}$ positive women were studied for cervical cytological changes in Papsmears who attended the department of pathology and Gynaecology, Government General Hospital, Guntur .According to the Clinical history ,Nulliparaous Women were 15(7.5\%), Para 1-2 were -148 (74\%), Para 3-4 were 36(18\%)and Paras 5 and above were $1(0.5 \%)$.According to the Socioeconomic status, women who were below the poverty line 173(86.5\%), women above were 27(13.5\%). According to the Nativity ,Urban patients were about $61(30.5 \%)$ and Rural patients were about $139(69.5 \%)$. According to the age at marriage, Women $<19$ years were $158(79 \%)$ and Women at 20-29 years were 42(21\%) Total Number of patients screened is 200.satisfactory smears were seen in $123(61.5 \%)$, and unsatisfactory smears in $77(38.5 \%)$. The cellular changes in cervical smears were studied according to The Bethesda System in 123 satisfactory smears.

The observations were shown in the following tables.

Table I: Shows Distribution of patients according to the age groups.

\begin{tabular}{|l|l|l|}
\hline Age in Years & No.of Patients & Percentage \\
\hline$<19$ & - & - \\
\hline $20-29$ & 58 & $47.15 \%$ \\
\hline $30-39$ & 55 & $44.71 \%$ \\
\hline $40-49$ & 10 & $8.13 \%$ \\
\hline Total & 123 & 100 \\
\hline
\end{tabular}

Table Ii: Shows no.of patients with Significant cytological changes in smears

\begin{tabular}{|l|l|l|}
\hline Age in Years & - ve for dysplasia /malignancy & With epithelial cell abnormalities \\
\hline$<19$ & - & - \\
\hline $20-29$ & $49(84.48 \%)$ & $9(15.52 \%)$ \\
\hline $30-39$ & $50(91 \%)$ & $5(9 \%)$ \\
\hline $40-49$ & $7(70 \%)$ & $3(30 \%)$ \\
\hline & $106(86.18 \%)$ & $17(13.82 \%)$ \\
\hline
\end{tabular}

Table Iii: Shows Analysis of Abnormal Cytological Findings in Relation to Age According to The Bethesda System

\begin{tabular}{|l|l|l|l|l|l|}
\hline Age in Yrs & No.of Patients & ASCUS & $\begin{array}{l}\text { AGC Endo } \\
\text { cervical }\end{array}$ & LSIL & HSIL \\
\hline$<19$ & - & - & - & - & - \\
\hline $20-29$ & 58 & $2(3.49 \%)$ & $1(1.72 \%)$ & $5(8.62 \%)$ & $1(1.72 \%)$ \\
\hline $30-39$ & 55 & - & $1(1.82 \%)$ & $4(7.27 \%)$ & - \\
\hline $40-49$ & 10 & - & - & $2(20 \%)$ & $1(10 \%)$ \\
\hline Total & 123 & $2(1.63 \%)$ & $2(1.63 \%)$ & $11(8.94 \%)$ & $2(1.63 \%)$ \\
\hline
\end{tabular}

Table Iv : Shows Distribution Of Patients According To Known Duration Of Hiv Infection

\begin{tabular}{|l|l|l|}
\hline Duration of infection in years & No.of Patients & Percentage \% \\
\hline $0-1$ & 24 & 19.51 \\
\hline $1-2$ & 16 & 13.0 \\
\hline $2-3$ & 15 & 12.2 \\
\hline $3-4$ & 17 & 13.82 \\
\hline $4-5$ & 19 & 15.45 \\
\hline $5-6$ & 9 & 7.32 \\
\hline $6-7$ & 8 & 6.5 \\
\hline $7-8$ & 4 & 3.25 \\
\hline $8-9$ & 4 & 3.25 \\
\hline $9-10$ & 4 & 3.25 \\
\hline $10-11$ & 1 & 0.81 \\
\hline $11-12$ & 2 & 1.62 \\
\hline
\end{tabular}




\begin{tabular}{|l|l|l|}
\hline Total & 123 & 100 \\
\hline
\end{tabular}

More number of patients seen with less than 1 year duration of infection, i.e., 24 (19.51\%).

Table - V: Shows Analysis Of Abnormal Cytological Findings In Relation To Duration Of Infection

\begin{tabular}{|l|l|l|l|l|l|}
\hline $\begin{array}{l}\text { Duration of } \\
\text { infection in } \\
\text { years }\end{array}$ & $\begin{array}{l}\text { No.of } \\
\text { patients }\end{array}$ & ASC-US & AGC endocervical & LSIL & HSIL \\
\hline $0-1$ & 24 & - & - & $2(8 . .33 \%)$ & $1(4.16 \%)$ \\
\hline $1-2$ & 16 & - & - & $2(12.5 \%)$ & - \\
\hline $2-3$ & 15 & - & - & $1(6.66 \%)$ & - \\
\hline $3-4$ & 17 & - & $2(11.76 \%)$ & $2(11.76 \%)$ & - \\
\hline $4-5$ & 19 & - & - & $1(5.26 \%)$ & $1(5.26 \%)$ \\
\hline $5-6$ & 9 & - & - & $2(22.22 \%)$ & - \\
\hline $6-7$ & 8 & $2(25 \%)$ & - & - & - \\
\hline $7-8$ & 4 & - & - & $1(25 \%)$ & - \\
\hline $8-9$ & 4 & - & - & - & - \\
\hline $9-10$ & 4 & - & - & - & - \\
\hline $10-11$ & 1 & - & - & - & - \\
\hline $11-12$ & 2 & - & - & - & - \\
\hline Total & 123 & 2 & 2 & 11 & 2 \\
\hline
\end{tabular}

Table - Vi: Shows Analysis Of Abnomral Cytological Findings In Relation To Pv Findings

\begin{tabular}{|l|l|l|l|l|l|l|}
\hline PV findings & $\begin{array}{l}\text { No.of } \\
\text { patients }\end{array}$ & ASC-US & $\begin{array}{l}\text { AGC } \\
- \text { Endocervical }\end{array}$ & LSIL & HSIL & $\begin{array}{l}\text { Total +ve for } \\
\text { SIL }\end{array}$ \\
\hline With erosion & 52 & $2(3.84 \%)$ & $2(3.84 \%)$ & $7(13.46 \%)$ & $2(3.84 \%)$ & 13 \\
\hline $\begin{array}{l}\text { Without } \\
\text { erosion }\end{array}$ & 71 & - & - & $4(5.63 \%)$ & 0 & 4 \\
\hline Total & 123 & 2 & 2 & 11 & 2 & 17 \\
\hline
\end{tabular}

Table - Vii: Shows Distribution of cases according to cytological findings

\begin{tabular}{|l|l|l|l|}
\hline S.No. & Cytological changes & No.of cases & Percentage \\
\hline 1 & $\begin{array}{l}\text { Inflammatory smears with squamous } \\
\text { metaplasia }\end{array}$ & 22 & $17.88 \%$ \\
\hline 2 & $\begin{array}{l}\text { Inflammatory smears with Trichomonas } \\
\text { vaginalis }\end{array}$ & 24 & $19.51 \%$ \\
\hline 3 & Inflammatory smears with candidiasis & 1 & $0.81 \%$ \\
\hline 4 & $\begin{array}{l}\text { Inflammatory smear with squamous } \\
\text { metaplasia and Trichomonas vaginalis }\end{array}$ & 1 & $13.82 \%$ \\
\hline 6 & Smears +ve for SIL & 17 & \\
\hline & $\begin{array}{l}\text { Infalmmatory smears with metaplasia } \\
\text { and AGC }\end{array}$ & 1 & \\
\hline
\end{tabular}

Table - Viii: Shows Distribution of patients in relation to STD

\begin{tabular}{|l|l|l|l|}
\hline Cytological findings & Positive for STD & Negative for STD & Total \\
\hline +ve for SIL & 9 & 8 & 17 \\
\hline -ve for SIL & 67 & 39 & 106 \\
\hline Total & $76(62 \%)$ & $47(38 \%)$ & $123(100 \%)$ \\
\hline
\end{tabular}

Table - Ix: Shows Distribution Of Patients In Relation To Antiretroviral Treatment

\begin{tabular}{|l|l|l|l|}
\hline Cytological Findings & With ART & Without ART & Total \\
\hline With abnormality & 9 & 8 & 17 \\
\hline Without abnormality & 47 & 59 & 106 \\
\hline Total & $56(46 \%)$ & $67(54 \%)$ & $123(100 \%)$ \\
\hline
\end{tabular}

\section{Discussion}

The aim of this study was to characterize cytological changes in cervical smears of 200 HIV seropositive women who attended the Departments of pathology and gynaecology , Government General Hospital, Guntur. The cases belonged to different reproductive age groups, different socio-economic classes and of urban and rural areas in Guntur District. Cytological evaluation was carried out on 123 satisfactory cervical smears. The study revealed maximum number of inflammatory smears $(81.3 \%)$, followed by smears showing squamous intra epithelial lesion $(13.82 \%)$ and smears with no significant cytological changes $(5.69 \%)$ were seen. Number of unsatisfactory smears were $77(38.5 \%)$. These smears were stained and examined but 
unsatisfactory for evaluation of epithelial abnormality because of inadequate squamous component, endocervical cells or squamous metaplastic cells and were obscured with blood and inflammatory cells.

\section{Inflammatory smears:-}

In their study Joshi et al $^{1}$ showed that out of 104 papsmears obtained from HIV seropositive women $38.5 \%$ (40/104) were inflammatory and $19.2 \%$ (20/104) were abnormal. This study also revealed women presenting with STD and HIV infection both, were 2.8 times more likely to have inflammatory papsmears and 3.5 times more likely to have abnormal papsmears compared to HIV seronegative women presenting without Sexually Transmitted Diseases. It was also observed that women at the age of 30 yrs i.e active sexual and reproductive age group and above $30 \mathrm{yrs}$ had only half the risk of having inflammatory cytology compared to those below 30 yrs. Mbakop A et $\mathrm{al}^{2}$ reported the incidence of inflammatory smears as 95.5\% (62/65) in HIV seropositive women. Micheletti et $\mathrm{al}^{3}$ stated that in a study conducted with 153 HIV seropositive women and 169 HIV seronegative women. The frequency of candidiasis, Trichomoniasis and bacterial vaginosis in cervical smears was almost equal in two groups. In our study the incidence of inflammatory smears with specific and nonspecific infections was about $81.3 \%(100 / 123)$.

\section{Non Specific inflammatory smears:-}

Archana Sharma et $\mathrm{al}^{4}$ have reported the incidence of nonspecific inflammatory smears as $64 \%(53 / 83)$ in HIV seropositive women. In their study Anuvat Roongpisuthipong et $\mathrm{al}^{5}$ reported the incidence of nonspecific inflammatory cases as $10.6 \%$ (51/482) in HIV women. Rashmi Bagga et $\mathrm{al}^{6}$ reported the incidence of non specific inflammatory smears as $20 \%$ in their study. Anorlu RI et $\mathrm{al}^{7}$ have reported the incidence of inflammatory smears as $15.7 \%$. A study done by O Fernandez-Limia et $\mathrm{al}^{8}$ showed the incidence of bacterial vaginosis with nonspecific inflammatory changes as $31.86 \%$. In our study the incidence of Nonspecific inflammatory smears was $42.27 \%(52 / 123)$. In our study smears show superficial and intermediate squamous epithelial cells with focal vacuolations in the cytoplasm. In focal areas nuclear enlargement with margination of chromatin seen. The smear shows plenty of neutrophils in the background.

\section{Inflammatory smears with candidiasis:-}

Archana Sharma et $\mathrm{al}^{4}$ reported the incidence of candidiasis as $34 \%$ in HIV positive women.

Anuvat Roongpisuthipong et $\mathrm{al}^{5}$ study showed that the incidence of vulvo-vaginal candidiasis as $20.3 \%$. The study done by $\mathrm{O}$ Fernandez Limia et $\mathrm{al}^{8}$ stated that the incidence of candidiasis was $13.27 \%$. Edenilson Eduardo Galore et $\mathrm{al}^{9}$ reported the incidence of candidiasis as $12.9 \%(19 / 147)$ in HIV positive women. Nimisha D Shethwala et al ${ }^{10}$ have reported the incidence as $17.14 \%(6 / 35)$ in HIV +ve women. In those studies diagnosis was done by gram staining, $\mathrm{KOH}$ smear and wet mount methods. In our study only one case reported as inflammatory smear with candidiasis. The incidence was $0.81 \%(1 / 123)$. Only cervical smears were evaluated in our study.In the present study papanicolaou stained smear shows basophilic hyphae. The squamous epithelial cells show perinuclear halo along with margination of chromatin. Focal areas show neutrophilic back ground in the vicinity of hyphae.

\section{Inflammatory smears with Trichomoniasis:-}

In their study, Frank Sorvillo et $\mathrm{al}^{11}$ stated that the incidence of Trichomoniasis was about $17.4 \%$ (37/212) in HIV seropositive women. They also observed that Trichomonas infection was the most frequently identified sexually transmitted disease. The infection was confirmed through wet film examination or by cytology smear study. Archana Sharma et $\mathrm{al}^{4}$ reported that the incidence was about $12 \%$. The study done by Susan et al ${ }^{12}$ showed the incidence of Trichomoniasis as 45\%.Edenilson Edurado Galore et al $^{9}$ stated that the incidence was $8.4 \%$ (13/147) in HIV positive women. Clara Menendez et $\mathrm{al}^{13}$ reported the Trichomoniasis incidence as $31 \%$, where as O Fernandez-Limia et al as $43.36 \%$. In our study the incidence of Trichomoniasis was about $19.5 \%$ (24/123). This was reported basing on indirect evidence of Trichomonas vaginalis infection like perinuclear halos and BB shots or cannon balls. In this study the smears show squamaous cells with increased eosinophilia. Trichomonads not seen in the smear. Aggregates of leukocytes covering the surfaces of the isolated mature squamous epithelial cells, known as BB shots or cannon balls and perinuclear halo are seen which are indirect evidence of Trichomonas vaginalis infection.

\section{Inflammatory smears with squamous metaplasia:-}

The authors Downes $\mathbf{J}$ and Wallace $\mathrm{JI}^{15}$, stated that the incidence of squamous metaplasia was about $28 \%(11 / 39)$ in HIV positive women. In our study the incidence of smears with squamous metaplasia was about $17.88 \%$ (22/123). In this study smears shows small mature squamous cells and also immature squanous like cells. Cells show increased N/C ratio with tails of cytoplasm. These are metaplastic squamous cells. 
Squamous intra epithelial Neoplasia (SIL):-

Incidence of squamous intra epithelial neoplasia varies according to different studies done by many authors. Incidence ranges from $2.9 \%$ to $42 \%$, in HIV seropositive women. Conti $\mathrm{M}$ et al ${ }^{15}$ study showed that the incidence was $42 \%$. LaRuchi et a ${ }^{16}$ stated that the incidence of SIL was $11.7 \%$.Edenilson et al ${ }^{9}$ study showed that as $12.6 \%$. In our study the incidence of squamous intra epithelial neoplasia was about $13.82 \%$. Our study was consistent with that of Edenilson et al study and differ from study of Conti $\mathrm{M}$ et al.

\section{Atypical squamous cells of undetermined significance:- (ASC-US)}

Anuvat Roong Pisuthipong et $\mathrm{al}^{5}$ have reported that the incidence of ASC-US was 4.8\%. Out of 123 cases studied 2 cases showed ASC-US in our study (1.63\%) we have not come across the cases of ASC-H in our study.In this study smears show squamous cells with mild increase in size of nucleus. Nuclear margins are with relative decrease in cytoplasm.

\section{Atypical glandular cells- Endocervical:-}

Adiha Misson Rua Micheletti et $\mathrm{al}^{3}$ reported the incidence of ASC-US and AGUS together as $7.8 \%$. In our study the incidence of AGC- endocervical was about 1.63\% (2/123).In our study smear diagnosed as AGC show sheets and small clusters of endocervical cells with enlarged nuclei and few oval nuclei are also seen. Overlapping of nuclei with hyperchromasia, granular chromatin and nucleoli are seen. Cells show very scanty cytoplasm.

\section{Low grade squamous intra epithelial lesion (LSIL):-}

In their study pimpika Tansupswatdikul et al ${ }^{17}$ reported that the incidence of LSIL was $6.4 \%(18 / 280)$ in HIV seropositive women. Anuvat Roongpisuthipong et $\mathrm{al}^{5}$ study showed that $11.2 \%$ had LSIL in their study. A study done by La Ruche et $\mathrm{al}^{16}$ stated that the incidence of LSIL was $7.6 \%$. In the present study the incidence of low grade squamous intra epithelial lesion was about $8.94 \%$ (11/123) and correlated with the studies of La Ruche et al. In our study smears show large mature polygonal squamous cells with enlarged nuclei (3-5 times).Nuclei shows hyperchromasia and evenly distributed finely granular chromatin. A few cells show pyknosis with chromatin smudging and wrinkling of nuclear contours. Perinuclear halo, thickening of cytoplasmic border and nuclear atypia seen.

High grade squamous intraepithelial lesion (HSIL):-

Pimpika Tansupswatdikul et al ${ }^{17}$ have reported that the incidence of High grade squamous intraepithelial lesion was $12.1 \%$ (34/28). Anuvat Roongpisuthipong et al ${ }^{5}$ 64study showed the incidence of HSIL as $4.1 \%$. In the present study the incidence of HSIL observed is $1.63 \%(2 / 123)$. In our study, smear shows smaller and less mature cells resembling parabasal and basal cells with abundant keratinized thin rim of immature cytoplasm. Nuclei are larger showing hyperchromasia, increased N/C ratio, irregular nuclear contours with granular chromatin. Nucleoli are absent. The cells are distributed singly and in small sheets. In our study we have not come across a case of Squamous cell carcinoma.

\section{Cases of squamous intraepithelial lesion in association with age:-}

La Ruche G et al ${ }^{16}$ study showed that LSIL seen in below 24 yrs of age and squamous cell carcinoma above 33yrs of age in HIV seropositive women. In the present study squamous intra epithelial neoplasia found in 17 cases (17/123) i.e; $13.82 \%$. In the age group $20-29$ yrs 9 out of 58 showed SIL (15.52\%) ,in 30-39 yrs 5 out of $55(9 \%)$ showed SIL, in 40-49 yrs 3 out of $10(30 \%)$ showed SIL. Peak incidence was noted in higher age group 40-49 yrs. This was consistent with the above studies. Sadeghi SB et $\mathrm{al}^{18}$ study showed SIL decreases with increasing age, because of decrease in risk factors in post menopausal women. Present study was done with women in reproductive age group (15-49yrs) only.

\section{Associaton with duration of HIV infection:-}

In their study Hluangdansakul $\mathrm{W}$ et al ${ }^{19}$ reported that there was statistically significant association between the duration of HIV infection and occurrence of SIL and squamous cell carcinoma. In our study more number of women seen with less than 1 yr duration of infection $19.51 \%(24 / 123)$. We observed increased incidence of squamous intraepithelial neoplasia in women with longer duration of HIV infection. 25\% incidence seen with 8yrs duration, $25 \%$ incidence seen with 7 yrs duration and $22.2 \%$ seen with 6yrs of duration. This was consistent with Hluangdansakul et $\mathrm{al}^{27}$ study. 


\section{Association with cervical erosion:-}

52 women $(42-27 \%)$ presented with cervical erosion out of which 13 women show squamous intra epithelial neoplasia $(25 \%)$. The incidence of SIL was much lesser in women without cervical erosion i.e; $5.63 \%$ (4/71). This revealed increased incidence of SIL among patients with cervical erosion.

\section{Association with presence of Sexually Transmitted Diseases (STD) :-}

Study done by S.Joshi et $\mathrm{al}^{1}$ stated that women presenting with STD and HIV both were 3.5 times more risk of having SIL compared to HIV seronegative women without STD. In the present study according to the presence of other sexually transmitted disease (like history of white discharge, genital ulcers, warts etc) the women with STD were $76(61.78 \%)$ and without STD were $47(38.21 \%)$. In patients with STD, out of 76, 9 cases showed SIL (11.84\%) and in patients without STD out of 47, 8 cases showed SIL (17.02\%). There was no association observed between STD and SIL in our study.

\section{Association with Antiretroviral therapy:-}

Joel M. Palefsky ${ }^{20}$ in his article stated that Highly active anti retroviral therapy (HAART) appears to have limited ability to clear HPV infection and induce regression of intra epithelial neoplasia in HIV positive women.In our study according to ART, women with ART were 56 (45.52\%) and women without ART were 67 (54.47\%). Cervical abnormal cytology seen in 9 out of $56(16.07 \%)$ in women with ART and 8 out of 67 $(11.94 \%)$ in women without ART. This showed increased incidence of SIL in women with ART. This was mainly due to less $\mathrm{CD}_{4}$ counts (Immunosuppression).

\section{Association with $\mathrm{CD}_{4}$ count:-}

In their study Cynthia et al (2009) ${ }^{22}$ revealed the risk of squamous intraepithelial lesion was more with $\mathrm{CD}_{4}<200$ cells $/ \mu \mathrm{l}$. In our study women with less than 200 cells/ $\mu 1$ were $29(23.57 \%)$. Women with more than 200 cells $/ \mu$ l were 69 (56.09\%). Women with unknown $\mathrm{CD}_{4}$ counts were $25(20.32 \%)$. Among these more incidence of squamous intra epithelial lesions were seen in women with $<200$ cells/ $\mu 1$, i.e; 6 out of $29(20.68 \%)$ where as 7 cases out of 69 shows SIL $(10.14 \%)$ in women with $>200$ cells/ $\mu$ l. So this study reflects more incidence of SIL associated with decreased $\mathrm{CD}_{4}$ cell counts $(<200 / \mu \mathrm{l})$ was consistent with the above studies. The other parameters observed in our study were Parity, socio economic status, nativity, age at marriage and history of opportunistic infections. More number of women came under para 1 and 2, i.e; 74\% (148/200). Women who were below the poverty line were $86.5 \%(173 / 200)$ where as women above the poverty line were $13.5 \%$ (27/200). Illiteracy, poor personal hygiene, illnourishment and vitamin deficiencies were also observed in low socio economic group. More number of women belonged to the rural areas, 69.5\% (139 out of 200) and urban women were about $30.5 \%$ (61 out of 200). In our study age at marriage was noted. Women who were married before $19 \mathrm{yrs}$ of age were $79 \%(158 / 200)$. We come across 69 women with either previous or present history of opportunistic infections (34.5\%) like oral thrush, skin rash, genital warts, ulcers and pulmonary tuberculosis.

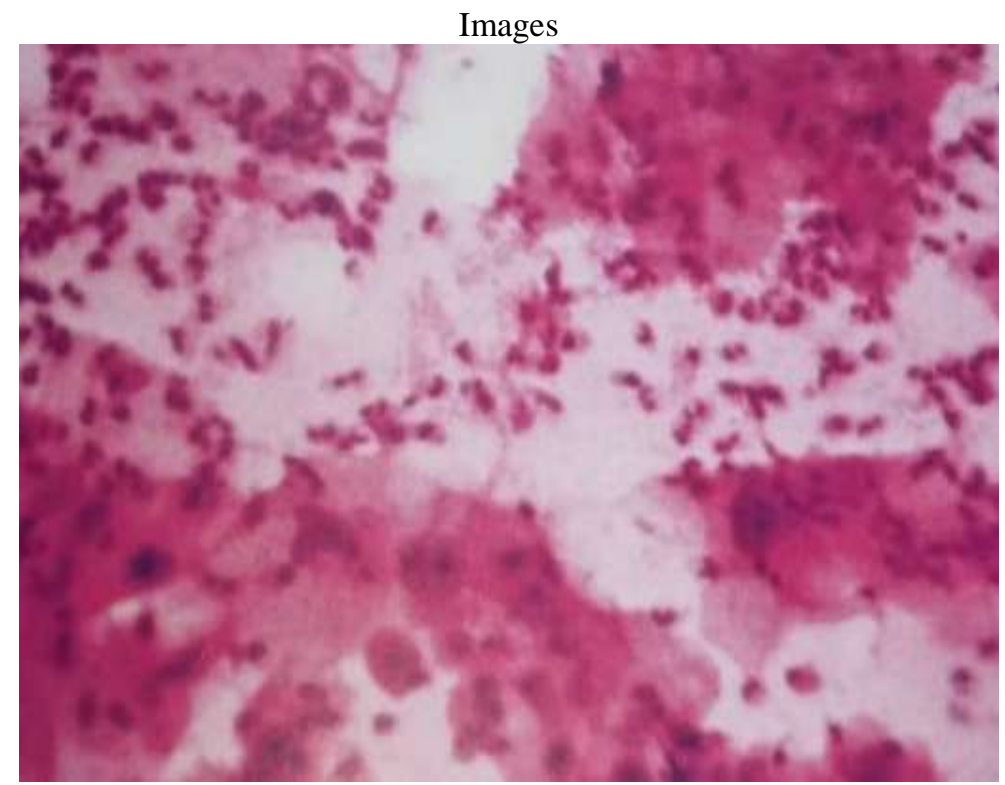


Pap Smear With Non specific Inflammatory changes in cervix

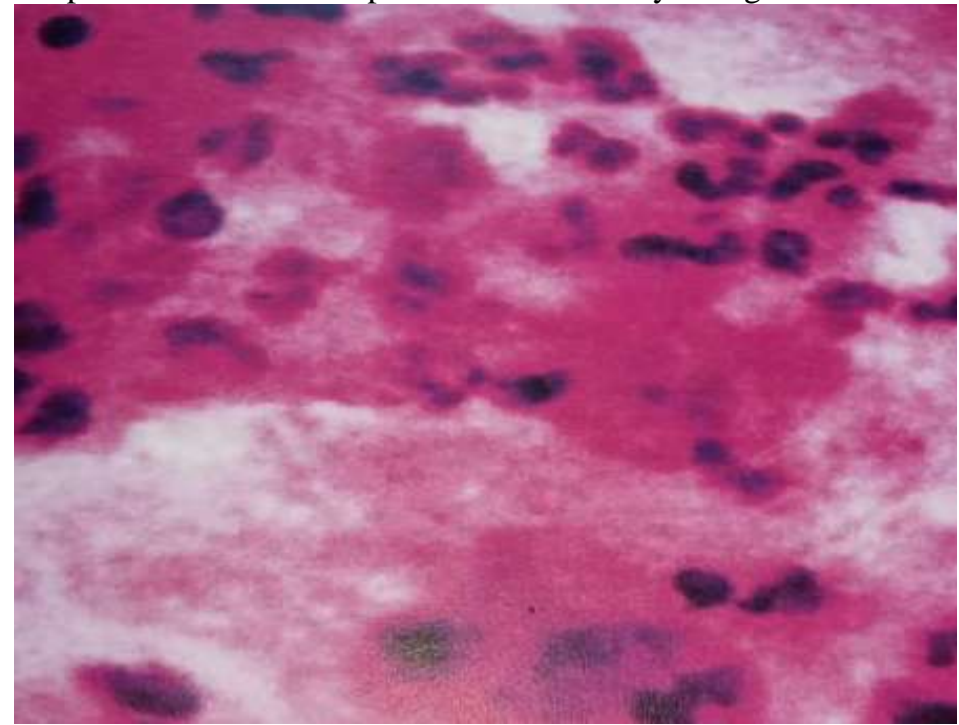

Pap Smear With Non Specific Inflammatory Changes In Cervix In High Power Field

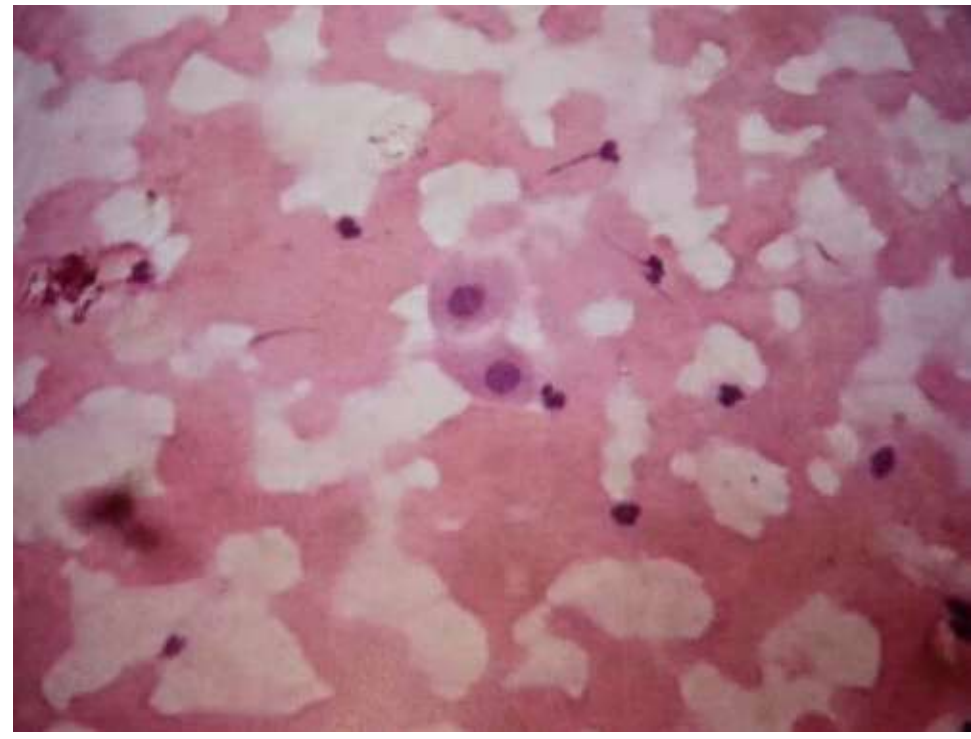

Smear With Ascus Showing Squamous Cells With Dysplastic Changes

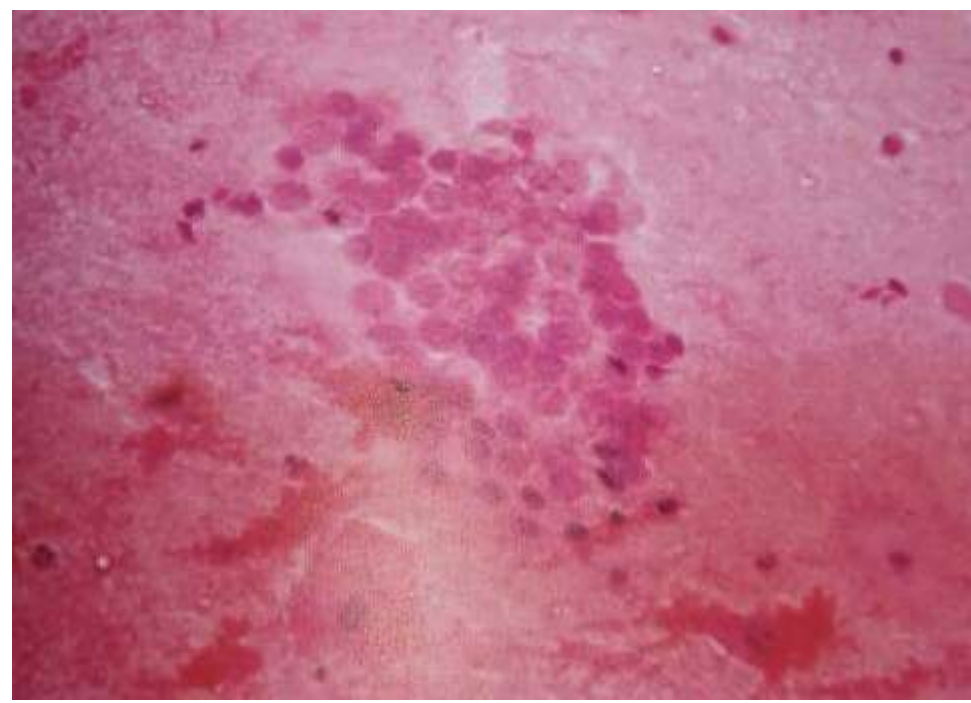

Pap Smear With Agc , Endocervical Cells Show Atypical Changes 


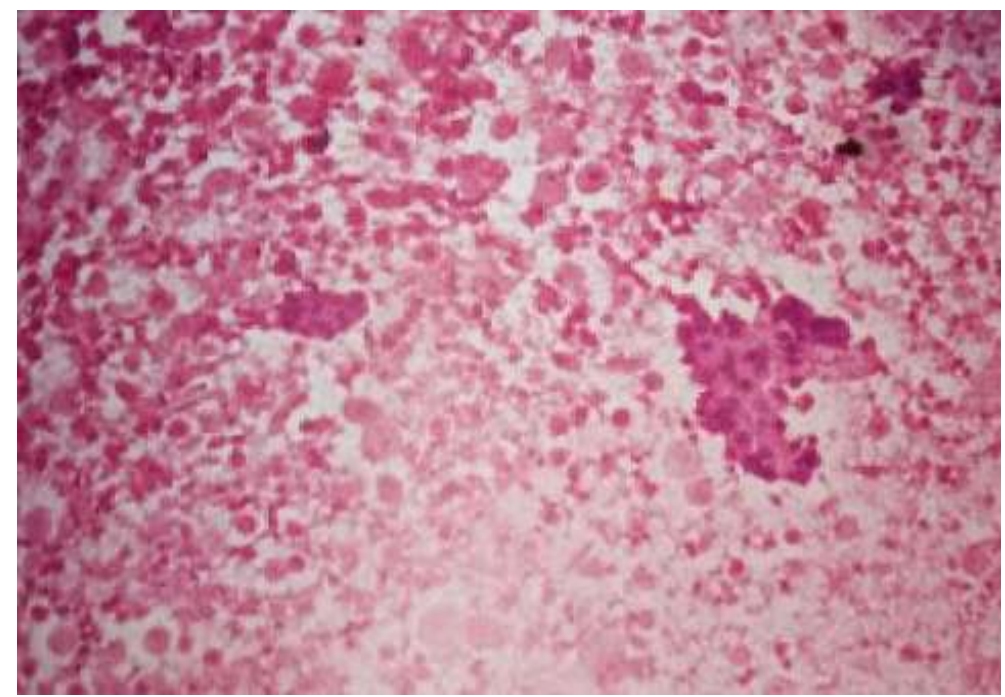

Pap Smear In Hsil- Lp View

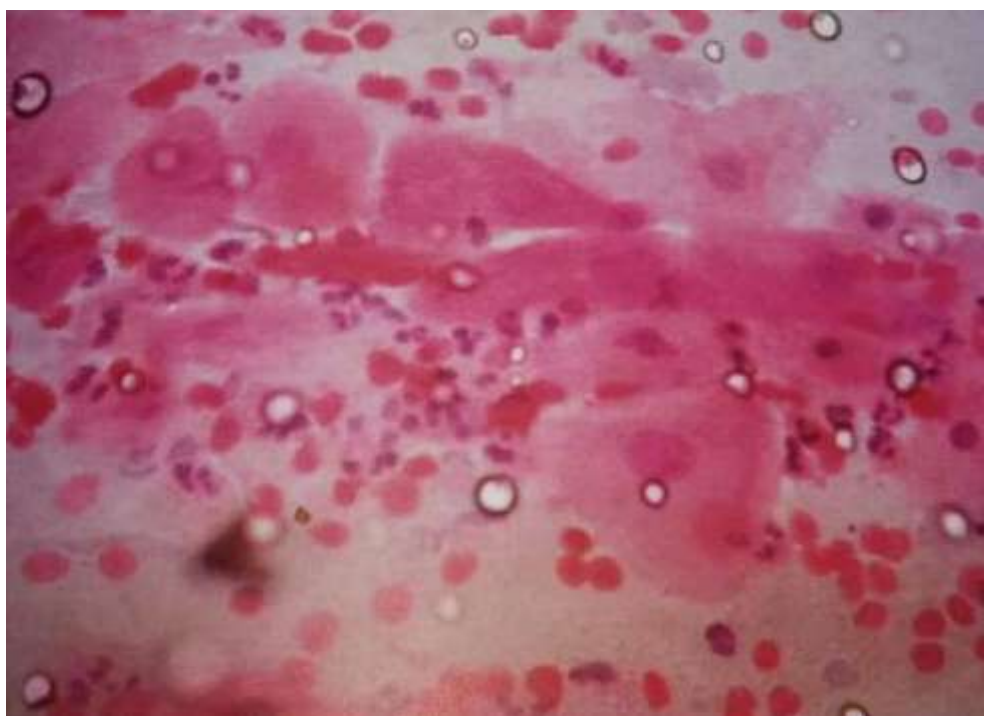

Pap Smear Show Metaplasic Squamous Cells

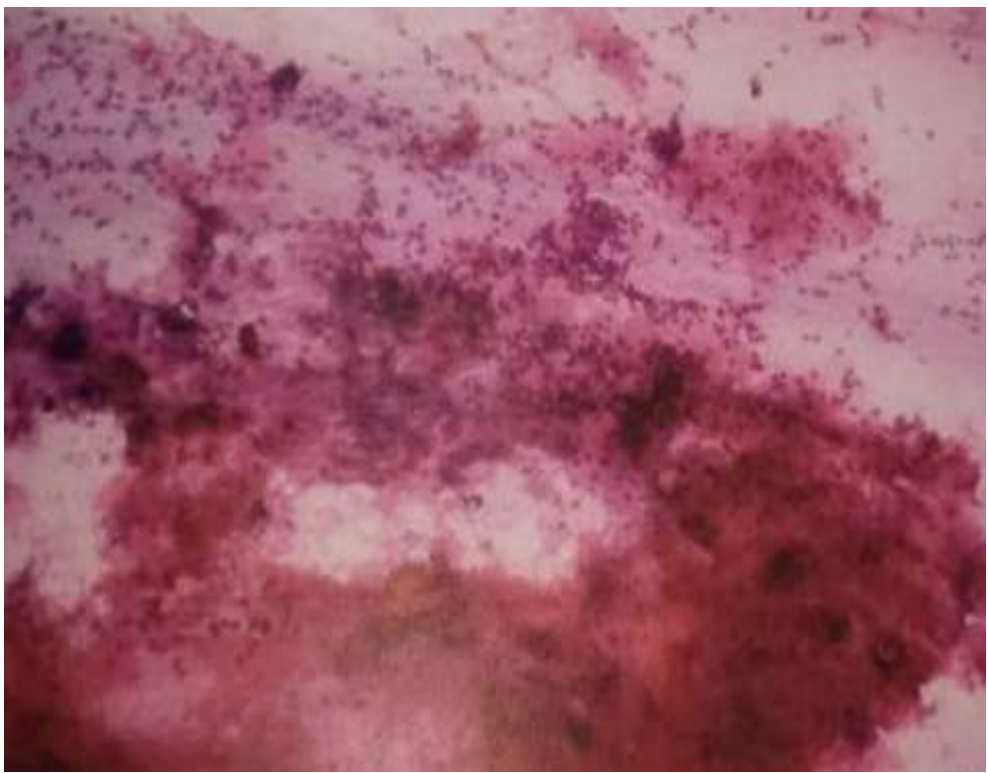

Pap Smear With Trichomonas Infection 


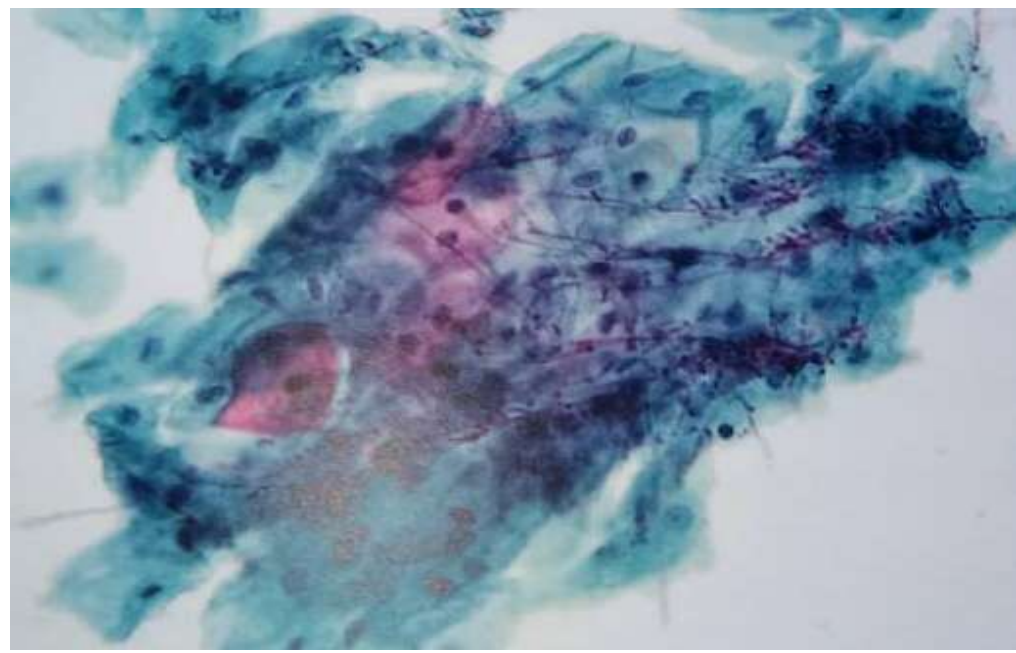

Pap Smear In Candidiasis

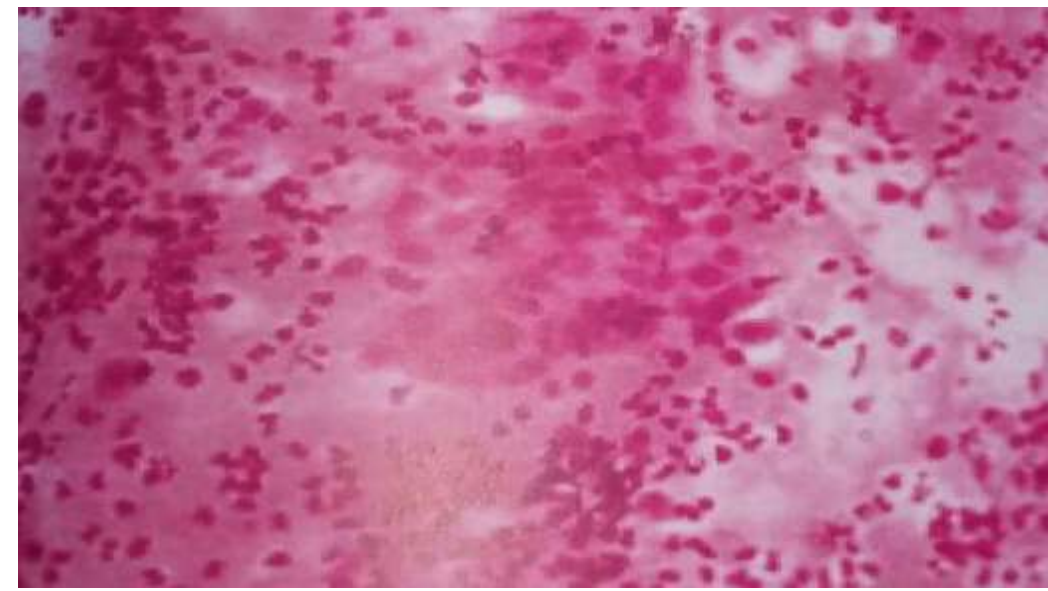

Pap Smear In Lsil

\section{Conclusion}

The study revealed maximum number of inflammatory smears (81.3\%), followed by smears showing squamous intra epithelial lesion (13.82\%). Early diagnosis of these lesions can reduce the morbidity of HIV seropositive patients. Thus cytological screening should gain much popularity and should be accessible to all. PAP smear can be recommended as a part of routine medical examination in gynaecological practice. Papanicolaou smear screening is an adequate tool for detecting cytologic changes in women with Human Immunodeficiency Virus. Cervical cancer is a preventable disease if women receive regular screening and timely followup and treatment after abnormal papanicolaou smear result.

\section{References}

[1]. S. Joshi, A. chandorkar, G. Krishnan etal cervical intraepithelial changes and HIV infection in women attending sexually transmitted disease clinics in Pune, India; Indian J Med Res 113, May 2001, pp 161-169.

[2]. Mbakop SM, Biggar RJ, Goedert JJ, Engels EA; Immune deficiency and risk for malignancy among persons with AIDS. J Acquir Immune Defic syndr 2003;32: 527-33.

[3]. Adiha Misson Rua Micheletti,etal cervico vaginal cytological abnormalities in patients with human immuno deficiency virus infection, in relation to disease stage, $\mathrm{CD}_{4}$ cell count and viral load; Diagnostic cytopathology, volume 37, Issue 3, PP 164-169, March 2009

[4]. Archana sharma, YS Marfatia, Megha Modi; Reproductive tract infections in HIV positive women: A case control study; Indian Journal of sexually transmitted Diseases, 2009, volume 30, Issue 1

[5]. Anuvat Roongpisuthipong, amphan chalemchock etal Operational Research for STD service: Improvement of Treatment and care at siriraj Hospital, siriraj Medical Journal, vol 61, Nov 1, 2009.

[6]. Rashmi Bagga, Ajay wanchu, Arvind Rajwanshi, KR Gupta, GRV Prasad, Sarala Gopalan, Papanicolaou smear abnormalities in HIV- infected women in North India; Asia- Pacific Journal of Clinical oncologyvolume 1, Issue 2-3, pages 77-80, Sep.2005.

[7]. Anorlu RI, Iqwilo CI, Akanmu AS, etal Prevalence of abnormal cervical smears among patients with HIV in Lagus, Nigeria, PMID/Net.

[8]. O Fernandez- Limia, C. Villar, etal Prevalence of Trichomoniasis, Bacterial vaginosis and candidiasis in women attending a sexual transmitted infections and gynaecologic clinic using as immunologic Latex Agglutination Test, The Internet Journal of Gynecology and obstetrics, 2007 volume 6, No:2. 
[9]. Edenilson Eduardo Calore, Sonia Maria Miranda. Pereera, Maria Jose cavellare; pregression of cervical lesions in HIV-seropositive women; A cytological study; Diagnostic cytopathology, volume 24, Issue 2 pp 117-119, Feb 2001

[10]. Nimisha D Shethwala, summaiya A Mulla, JK Kosambiya, vikas K. Desar; sexually transmitted infections and reproductive tract infections in female sex workers; Indian Journal of pathology and Microbiology, year 2009, vol 52, Issue 2 page 198-199.

[11]. Frank sorvillo, Andrea kovacs, Peter kerndt,etal ; Risk factors for Trichomoniasis among women with Human immuno deficiency virus (HIV) infection at a public clinic in Los Angeles county, California: Implications for HIV prevention, Am J Trop. Med. Hyg. 58 (4), 1998

[12]. Susan CD-uvin, Katherine Flanagan, Kimberly culff,etal ; Cervical Dysplasia among incarcerated women: A comparison of HIV seropositive and HIV- sero negative Inmates; Journal of women' s Health, vol 5, Issue 6.

[13]. Clara Menendez, Xavier castellsague, etal prevalence and Risk factors of sexually transmitted infections and cervical neoplasia in women from a Rural area of southern Mozambique; Infections Diseases in Obstetrics and Gynaecology, volume 2010,

[14]. Downes J, Wallace JI, A review of papanicolaou (pap) smears in HIV positive vs. HIV negative women in a drug treatment program, Int Conf AIDS. 1991 Jun 16-21;7;284.

[15]. Conti M. Agarossi A, parazzini F, Mugglasca ML, Boschini A, Negri E, casolati E; HPV, HIV infection, and risk of cervical intraepithelial neoplasia in former intravenous drug abusers; Gynecol oncol, 1993, Jun:49(3); 344-8.

[16]. LaRuche G. Ramon R, etal, squamous intraepithelial lesions of the cervix, invasive cervical carcinoma and immuno suppression induced by human immunodeficiency virus in Africa, Dlyscer- CI group; cancer- 1998 Jun 15: 82(12): 2401-8.

[17]. Pimpika Tansupswatdikul MD, Somkid Piyaman MD, prevalence and predictors of Abnormal cervical cytology in HIV- Infected Patients at the Anonymous clinic, Chonburi Hospital, Thai Journal of Obstetrics and Gynaecology, January 2009, vol.17.

[18]. Sadeghi SB, Sadeghi A, Robboy SJ (1988),prevalence of dysplasia and cancer of the cervix in a nation wide planned parent hood population cancer(Phila) 61: 2359-2361.

[19]. Hluangdansakul W, Phinchantra P, Bowonwatanu wong c; Prevalence of SIL and SCCA in human immuno deficiency virusseropositive women at anonymous clinic in chonburi Hospital, J Med Assoc Thai, 2006, Mar:89 (3); 289-93.

[20]. Joel M. Palefsky, cervical human papilloma virus infection and cervical intra epithelial neoplasia in women positive for human immuno deficiency virus in the era of highly active antiretro viral therapy, curropin oncol 15:382-388.

[21]. Guillem sirera, Sebastia videla, Raquel Lopez- Blaquez, etal . Highly active antiretroviral therapy and incidence of cervical squamous intraepithelial lesions among HIV-infected women with normal cytology and $\mathrm{CD}_{4}$ counts above $350 \mathrm{cells} / \mathrm{mm}^{3}$; Journal of Anti microbial chemotherapy, vol.61, Issue 1 pp 191-194. 